\title{
Effect of Sea Level Rise and Groundwater Withdrawal on Seawater Intrusion in the Gulf Coast Aquifer: Implications for Agriculture
}

\author{
Faye Anderson, Najla Al-Thani \\ Independent Scholars, Houston, TX, USA \\ Email: andersonfaye7@gmail.com
}

Received 14 February 2016; accepted 25 April 2016; published 28 April 2016

Copyright (C) 2016 by authors and Scientific Research Publishing Inc.

This work is licensed under the Creative Commons Attribution International License (CC BY). http://creativecommons.org/licenses/by/4.0/

\section{(c) (i) Open Access}

\begin{abstract}
The two main factors contributing to depletion of freshwater resources are climate change and anthropological variables. This study presents statistical analyses that are local in its specifics yet global in its relevance. The decline in Gulf Coast aquifer water quality and quantity has been alarming especially with the increased demand on fresh water in neighboring non-coastal communities. This study used seawater levels, groundwater use, and well data to investigate the association of these factors on the salinity of water indicated by chloride levels. Statistical analyses were conducted pointing to the high significance of both sea water level and groundwater withdrawals to chloride concentrations. However, groundwater withdrawal had higher significance which points to the need of water management systems in order to limit groundwater use. The findings also point to the great impact of increased groundwater salinity in the Gulf Coast aquifer on agriculture and socioeconomic status of coastal communities. The high costs of desalinization point to the increased signification of water rerouting and groundwater management systems. Further investigation and actions are in dire need to manage these vulnerabilities of the coastal communities.
\end{abstract}

Keywords

Sea Level Rise, Groundwater, Gulf Coast Aquifer, Coastal Vulnerability, Rerouting

\section{Introduction}

Groundwater makes up about one third of Earth's freshwater and is the primary source of clean water for more

How to cite this paper: Anderson, F. and Al-Thani, N. (2016) Effect of Sea Level Rise and Groundwater Withdrawal on Seawater Intrusion in the Gulf Coast Aquifer: Implications for Agriculture. Journal of Geoscience and Environment Protection, 4, 116-124. http://dx.doi.org/10.4236/gep.2016.44015 
than 1.5 billion people worldwide and more than fifty percent of the United States (US) population. The main four issues with groundwater are overdraft, waterlogging, seawater intrusion, and pollution. The direct effects of climate change include groundwater recharge, discharge, storage, saltwater intrusion, biogeochemical reactions, chemical fate, and transport. Whereas climate change indirect effects are anthropological factors which exacerbate the direct effects [1]-[3]. Research has provided mixed results when comparing the impact of direct and indirect effects with spatial variations [4].

The sharp interface between fresh groundwater and coastal salt water is affected by climate change due to the continual increase in sea level resulting from glacial melt and thermal expansion of water. By 2001, sea level has risen globally by $25 \mathrm{~cm}$ [3]. The increase in sea water level increases the height of water table which in turn results in subsurface flooding. This impacts septic systems, infrastructure, wetlands, and ecosystems [5] [6]. Another effect of sea level rise on groundwater is increased salinity. Fresh water pumping from coastal aquifers wells lowers the water table level below sea level which increases saltwater intrusion [4] [7] [8].

The Gulf Coast aquifer is a major aquifer system extending from the Texas-Louisiana Border in the northeast to the Texas-Mexico border in the south. It is a heterogeneous complex system where the fluctuations of sea level throughout history resulted in sedimentary depositions in the coastal plains of the Gulf of Mexico Basin. Sediments of sand and clay continued to deposit with the change of sea level [9]. According to Texas Water Development Board (TWDB), freshwater saturated thickness in the aquifer averages about 1000 feet and the quality of its water varies with both depth and location being better in the north and declining to the south. Moreover, increased extraction has led to land subsidence in the most populated counties like Harris County and Fort Bend County [10]. The vulnerability of this coastal aquifer to increased extraction and climate change has impacted fresh water availability and caused increased flooding [7]. These lead to socioeconomic effects including displacement, evacuations, and public health issues. These impacts combined with other issues facing coastal communities in Texas and other places in the world, makes it more complicated to mitigate and manage the issues [11]-[18]. Disparity of impacts affect groups of lower income, non-English speakers, and vulnerable age groups (65 years or older, 5 years or younger) [14]. Seawater intrusion to the Gulf Coast aquifer is complicated and can take one or more of these three forms: lateral intrusion from the Gulf of Mexico; upward intrusion from deeper, more saline zones of a groundwater system; and downward intrusion from coastal waters [19].

The objective of this study was to study the effect of sea level rise (direct climate change effect) and groundwater withdrawal (anthropologic indirect effect) on sea water intrusion in the Gulf Coast aquifer. The effects of these factors on the concentrations of chloride sampled from groundwater wells were investigated. Chloride is one of seawater intrusion indicators due to its chemical stability and similarity of its intruding rate to seawater's [20]. Chloride concentration in the Gulf Coast aquifer, among other constituents has been on the increase [21].

Although chloride has a maximum contaminant level (MCL) of $250 \mathrm{mg} / \mathrm{L}$ [22], a concentration of $100 \mathrm{mg} / \mathrm{L}$ or more has been assumed to indicate seawater intrusion [20] [23].

\section{Methods}

Monthly mean sea level data were downloaded from Sea Level Trends website developed by the National Oceanic and Atmospheric Administration (NOAA) [24]. Total chloride (Cl) in mg/L concentration along with other variables for the wells of Gulf Coast aquifer (Table 1) was extracted from the website of TWDB [25]. Estimated Use of Water in the United States County-Level Data for 2010 variables were downloaded from the United States Geological Survey (USGS) website [26]. Variables downloaded include total public supply groundwater withdrawals, domestic self-supplied fresh groundwater withdrawals, total industrial self-supplied groundwater withdrawals, fresh groundwater withdrawals for irrigation, fresh groundwater withdrawals for livestock, total groundwater withdrawals for aquaculture, and total groundwater withdrawals, in millions of gallons of water used per day (Mgal/d).

Statistical analyses were conducted at 0.05 significance level using GeoDa 1.6.7 [27]. ArcMap 10.3.1 was used for mapping [28]. Ordinary least squares with spatial dependence regression analyses were conducted. Spatial weights matrix was formed using wells longitude and latitude data [11] [29]-[31]. The spatial regression performed has the equation $[\mathrm{Cl}]=$ intercept + longitude + latitude +distance to the Gulf of Mexico + sea level + groundwater withdrawals + spatial residual.

\section{Results}

Data for the twenty years from 1996 to 2015 were extracted and linked into one dataset. Summary statistics for 
chloride and $\mathrm{pH}$ are presented in Table 2. Annual average chloride has been higher than MCL except for year 2005 (247.28 mg/L). T-test and Fisher's F-test were conducted to test the hypothesis of changing means and variances respectively, between each two years (Figure 1). Tests' results led us to conclude that the means and variances for chloride have changed across the years. $\mathrm{pH}$ average remained near the neutral level of 7 (Figure 2). Figure 3 presents groundwater well locations along with their highest chloride concentrations during the twenty years from 1996 to 2015. The number of values was 177. Higher concentrations were concentrated in southern parts of the Gulf Coast Aquifer. Figure 4 presents the total groundwater withdrawals for 2010 in millions of gallons per day. Harris County (Houston, population of more than 5 million) was on top of the counties. Figure 5 presents a comparison of groundwater withdrawals percentage from the Gulf Coast aquifer per use. With more than sixty six percent groundwater withdrawal, irrigation is the major groundwater use in the communities of the Gulf Coast aquifer.

Kurtosis and skewness of chloride were 29.31 and 4.43 respectively. This indicates departure from normality and justified the application of logarithmic transformation in order to comply with regression assumptions. Pair-wise correlation coefficients are presented in Table 3. The pair-wise correlations between chloride and $\mathrm{pH}$ were low whereas the pair-wise association between the distance to the Gulf of Mexico and mean sea level was slightly higher. Correlation between chloride sampled from 1996 to 2014 and mean sea levels for the same years was 0.11 but kept increasing to 0.31 for the years 1900 and 1958. Table 4 presents the pair-wise associations between wells' chloride concentrations and their counties' groundwater withdrawal. All correlations except with withdrawal for livestock were negatively associated to chloride levels. Regression F-statistic came out significant and R-squared was 53\%. Nevertheless, mean sea level was statistically significant with a p-value of 0.02 and a regression coefficient of 2.62, $\mathrm{pH}$ was not significant, and the distance to the Gulf of Mexico was significant

Table 1. List of variables downloaded and analyzed.

\begin{tabular}{cl}
\hline Variable & Source \\
\hline Aquifer Name & TWDB \\
Latitude for the well location & TWDB \\
Longitude for the well location & TWDB \\
Sample Month & TWDB \\
Sample Day & TWDB \\
Sample Year & TWDB \\
County Name & TWDB \\
Chloride (mg/L) & TWDB \\
Well Depth (ft) & TWDB \\
Groundwater withdrawals & USGS \\
Sea level trends & NOAA \\
\hline
\end{tabular}

Table 2. Summary statistics for groundwater chloride and $\mathrm{pH}$ in the gulf coast aquifer.

\begin{tabular}{cccccccccccccc}
\hline & 1996 & 1997 & 1998 & 1999 & 2000 & 2001 & 2002 & 2005 & 2006 & 2009 & 2010 & 2013 & 2015 \\
\hline Min Cl & 46.00 & 8.00 & 320.00 & 148.00 & 68.30 & 8.44 & 309.00 & 28.00 & 50.00 & 3.16 & 228.00 & 4.56 & 217.00 \\
Average Cl & 293.19 & 356.22 & 320.00 & 865.48 & 449.72 & 470.20 & 1023.00 & 247.28 & 498.64 & 336.07 & 228.00 & 282.14 & 762.33 \\
Std. Dev. Cl & 301.13 & 825.67 & 203.00 & 926.43 & 535.12 & 996.77 & 858.22 & 209.83 & 679.83 & 429.81 & 305.00 & 348.41 & 907.56 \\
Max Cl & 853.30 & 6541.00 & 320.00 & 3920.00 & 1490.00 & 6840.00 & 2160.00 & 1110.00 & 2020.00 & 1490.00 & 228.00 & 1510.00 & 1810.00 \\
Min pH & 7.10 & 5.73 & 8.10 & 6.97 & 6.77 & 6.18 & 7.83 & 6.24 & 6.48 & 5.20 & 8.02 & 4.77 & 6.57 \\
Average pH & 7.78 & 7.38 & 8.10 & 7.44 & 7.20 & 7.23 & 7.87 & 7.33 & 7.21 & 7.30 & 8.02 & 7.32 & 7.24 \\
Std. Dev. pH & 0.36 & 0.50 & 0.70 & 0.46 & 0.26 & 0.51 & 0.06 & 0.54 & 0.46 & 0.75 & 0.01 & 0.76 & 0.59 \\
Max pH & 8.20 & 8.95 & 8.10 & 8.42 & 7.50 & 8.61 & 7.91 & 8.42 & 7.73 & 9.67 & 8.02 & 8.23 & 7.68 \\
\hline
\end{tabular}


Table 3. Pair-wise associations between chloride concentration and the three variables.

\begin{tabular}{|c|c|c|c|}
\hline & $\begin{array}{c}\mathrm{pH} \\
1996-2014\end{array}$ & $\begin{array}{l}\text { Distance to the Gulf of Mexico } \\
1996-2014\end{array}$ & $\begin{array}{c}\text { Mean Sea Level } \\
1900-1958\end{array}$ \\
\hline Cl 1996-2014 & 0.04 & 0.15 & 0.31 \\
\hline
\end{tabular}

Table 4. Pair-wise correlation coefficients between chloride concentration and the groundwater withdrawal variables.

\begin{tabular}{cc}
\hline Groundwater Withdrawal Variables & $\mathrm{Cl}(\mathrm{mg} / \mathrm{L})$ \\
\hline Public Supply, groundwater withdrawals, total, in Mgal/d & -0.089996493 \\
Domestic, self-supplied groundwater withdrawals, fresh, in Mgal/d & -0.113263524 \\
Industrial, self-supplied groundwater withdrawals, total, in Mgal/d & -0.129418839 \\
Irrigation, groundwater withdrawals, fresh, in Mgal/d & -0.22733962 \\
Livestock, groundwater withdrawals, fresh, in Mgal/d & 0.047510713 \\
Aquaculture, groundwater withdrawals, total, in Mgal/d & -0.100836603 \\
Total groundwater withdrawals, total (fresh + saline), in Mgal/d & -0.219060339 \\
\hline
\end{tabular}

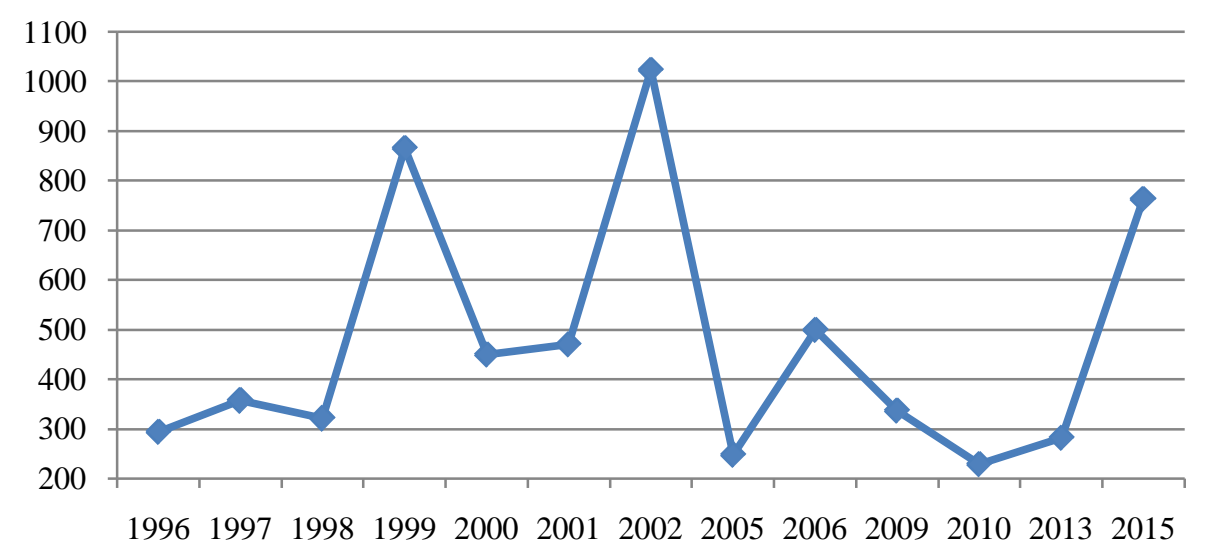

Figure 1. Annual average for chloride (mg/L) for groundwater sampled from the gulf coast aquifer.

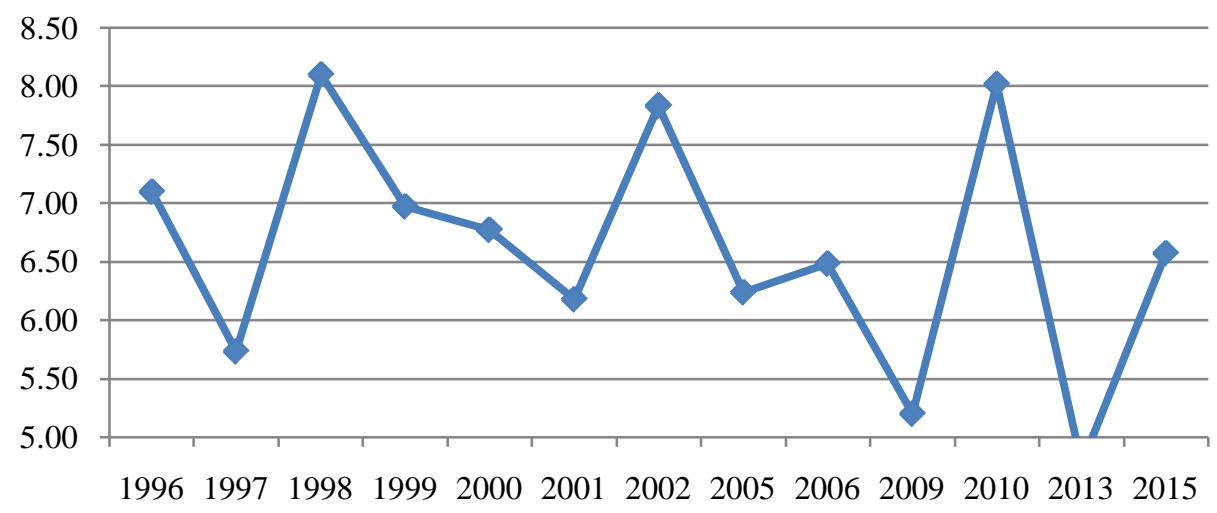

Figure 2. Annual average $\mathrm{pH}$ for groundwater sampled from the gulf coast aquifer.

with a regression coefficient of -1.02 . The seven county groundwater withdrawal variables were highly significant to chloride levels. All except withdrawal for livestock and total withdrawals were negatively associated with the dependent variable (Table 5). 


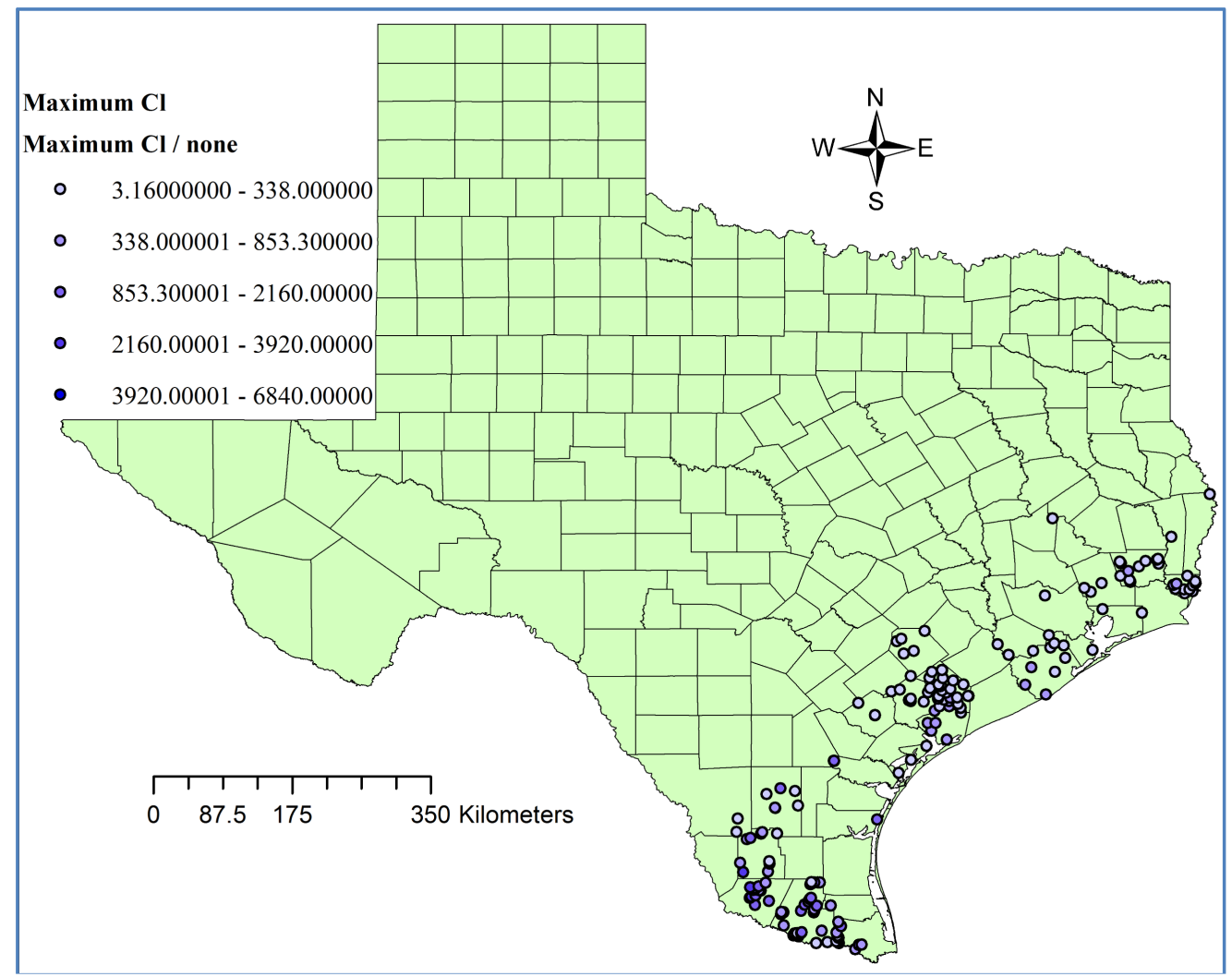

Figure 3. Maximum chloride concentrations, 1996-2014.

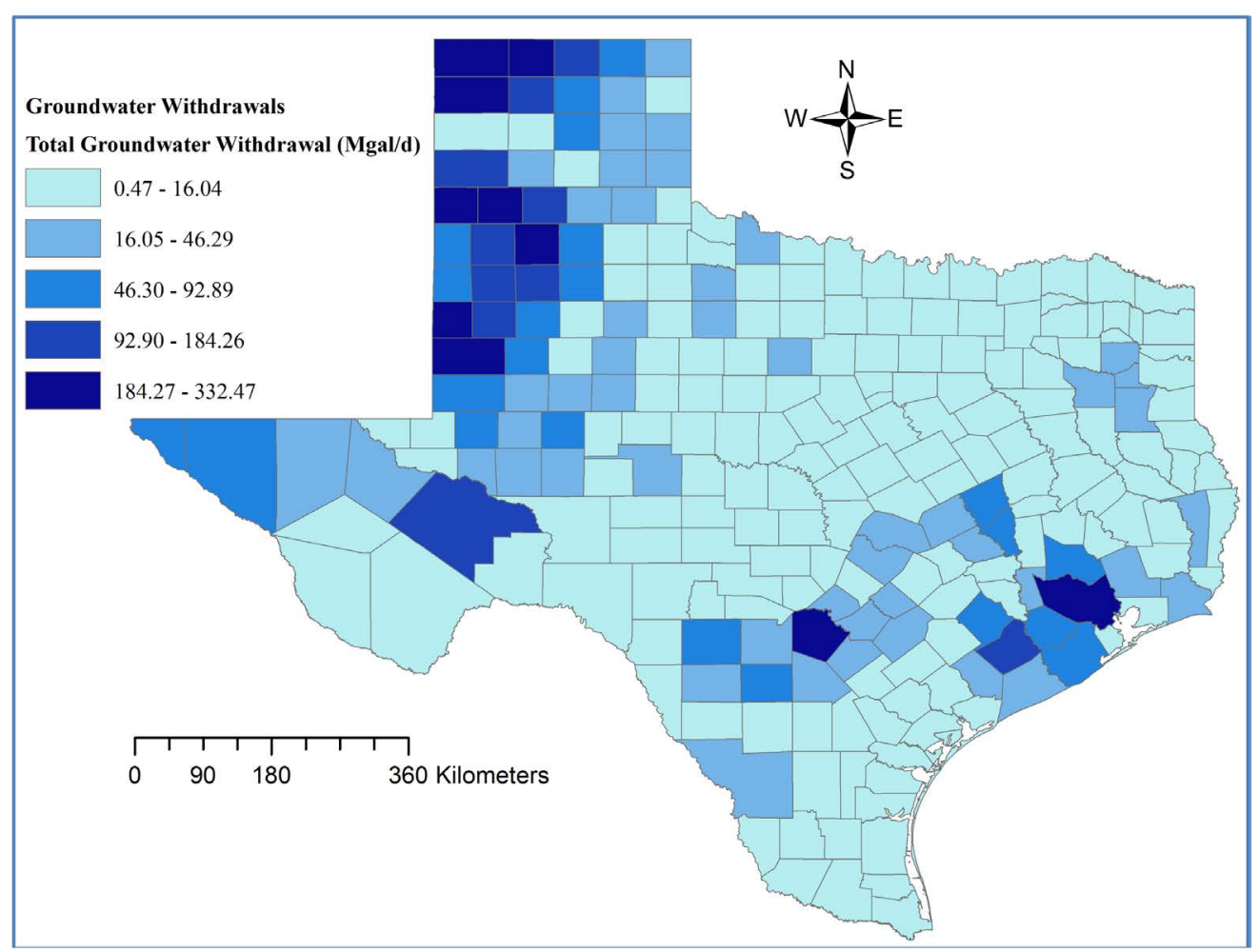

Figure 4. Total groundwater withdrawals for each county in 2010, in millions of gallons per day [26]. 


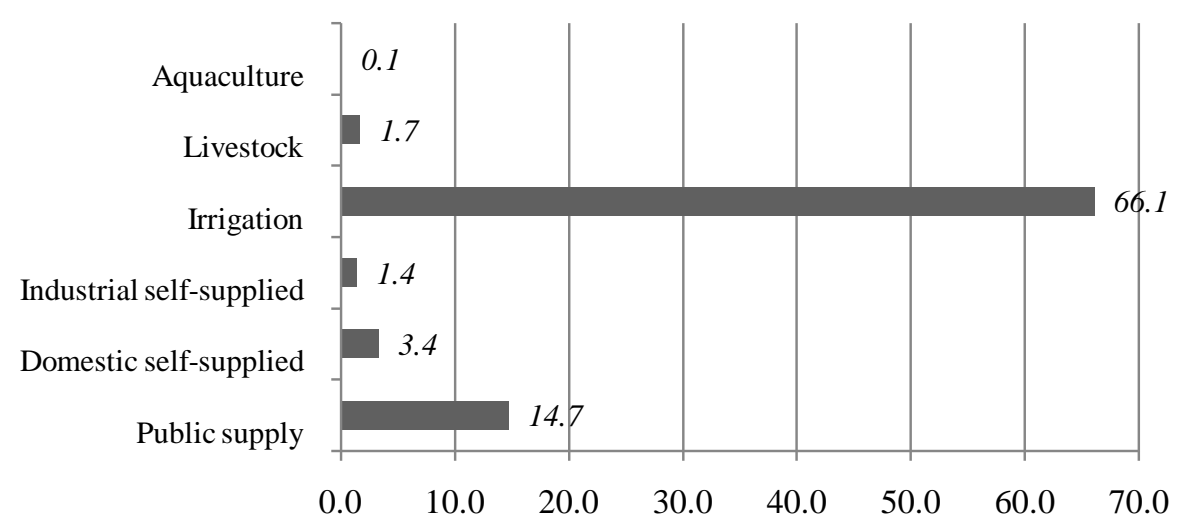

Figure 5. Groundwater withdrawal percentages per use in 2010 [26].

Table 5. Ordinary least squares spatial regression coefficients.

\begin{tabular}{ccc}
\hline Variable & Coefficient & Probability \\
\hline Constant & 6.96 & 0.00 \\
$\mathrm{pH}$ & -0.05 & 0.40 \\
Distance to the Gulf of Mexico & -1.02 & 0.00 \\
Mean Sea Level & 2.62 & 0.02 \\
Public Supply, groundwater withdrawals, total, in Mgal/d & -0.12 & 0.00 \\
Domestic, self-supplied groundwater withdrawals, fresh, in Mgal/d & -0.27 & 0.00 \\
Industrial, self-supplied groundwater withdrawals, total, in Mgal/d & -0.24 & 0.00 \\
Irrigation, groundwater withdrawals, fresh, in Mgal/d & -0.16 & 0.00 \\
Livestock, groundwater withdrawals, fresh, in Mgal/d & 1.43 & 0.00 \\
Aquaculture, groundwater withdrawals, total, in Mgal/d & -1.45 & 0.00 \\
\hline
\end{tabular}

\section{Discussion}

The high chloride concentration is a strong indicator of seawater intrusion [23] especially in wells within proximity of salt water bodies like the Gulf of Mexico. Annual average concentrations had high variations from 1996 to 2015. This is attributed to variations in the hydrologic cycle. According to the Intergovernmental Panel on Climate Change (IPCC), climate change increased precipitation variability in the US. Increased precipitation (with uncertain amounts) is caused by increased water vapor and evaporation associated with warmer temperatures. The change in precipitation varies from one region to another but has resulted in higher risks of flooding, decrease in summer water supply, and decrease of both surface and ground water quality [3] [18]. However, the United States Environmental Protection Agency (EPA) claims that the increase in precipitation in the US is estimated to be $6 \%$ whereas it is $2 \%$ worldwide [32].

The spatial variation in chloride groundwater concentrations could be attributed to two factors: recharge and variations in population water use. Recharge is at its lowest in the southern parts of the Gulf Coast Aquifer [33]. The 95 year rolling window pair-wise association between chloride concentrations and sea water levels is supported by the characteristic timescale of 100 - 200 years of ocean thermal expansion due to global warming [34].

Increased withdrawal of groundwater has deteriorated the quality of groundwater. This study contributes to the ongoing debate on the impacts of sea level rise versus withdrawal where the anthropological effects have more severe impacts [4]. This is supported by the higher statistical significance for groundwater withdrawal variables than that for sea level (Table 5) and the increased percentage of irrigation groundwater withdrawal (Figure 5). 
Relevant mitigations include rerouting water, desalinization, seawater injection wells [8], and demand management through legislation [35] [36]. Groundwater management systems are interpreted in decisions controlling the volume of water withdrawn annually from the aquifer, location of pumping and artificial recharge wells and their rates, and groundwater contamination control [37]. The high costs of desalinization make them a very expensive remedy for irrigation [38]. Hence, more efforts need to be directed towards water rerouting and management systems.

\section{Conclusion}

The primary goal of this study was to assess the effects of sea level and groundwater withdrawal on chloride levels in the Gulf Coast aquifer, as a proxy to sea water intrusion in the coastal aquifer. Data were extracted from three sources: NOAA, TWDB, and USGS. Statistical analyses demonstrated that temporal and spatial variability of chloride concentrations as well as its statistically significant associations with sea level and groundwater withdrawals. Validation demonstrated the robustness of the model. The findings support the calls for better water management especially in the southern communities where higher chloride concentrations were measured. Moreover, the viability of interventions like seawater barrier injection wells should be explored. Analyses point to the increased importance of water management and policies in order to protect freshwater sources especially for irrigation. Finally, in order to overcome the limitations of the study, further wider investigations are recommended for different coastal aquifers.

\section{Strengths and Limitations}

To our knowledge, this is the first study to estimate the statistical significance between groundwater salinity and both sea level and groundwater use for the Gulf Coast major aquifer. Despite the low R-squared value (53\%) of the ordinary least square spatial regression, the analysis captured important predictors of groundwater chloride level.

Groundwater withdrawal data are at the county level [39]. Future research could benefit from groundwater extraction (pumpage) more accurate quantities at the well level. Also, the latest available data are for 2010 which is six years behind the timeframe of the study.

\section{References}

[1] Winkler, A. (2013) Climate Change Effects on Groundwater Resources: A Global Synthesis of Findings and Recommendations. In: Treidel, M.-B.J. and Gurdak, J.J., Eds., Environmental Earth Sciences, Springer Science \& Business Media B.V., 1937-1939.

[2] Taylor, R.G., et al. (2013) Ground water and Climate Change. Nature Climate Change, 3, 322-329. http://dx.doi.org/10.1038/nclimate1744

[3] Romero-Lankao, P., et al. (2014) North America. In: Barros, V.R., Field, C.B., Dokken, D.J., Mastrandrea, M.D., Mach, K.J., Bilir, T.E., Chatterjee, M., Ebi, K.L. and Estrada, R.C.G.Y.O., Girma, B., Kissel, E.S., Levy, A.N., MacCracken, S., Mastrandrea, P.R. and White, L.L., Eds., Climate Change 2014: Impacts, Adaptation, and Vulnerability. Part B: Regional Aspects. Contribution of Working Group II to the Fifth Assessment Report of the Intergovernmental Panel on Climate Change, Cambridge University Press, Cambridge.

[4] Ferguson, G. and Gleeson, T. (2012) Vulnerability of Coastal Aquifers to Groundwater Use and Climate Change. Nature Climate Change, 2, 342-345. http://dx.doi.org/10.1038/nclimate1413

[5] Anderson, F. (2015) The Development of Rural Sustainability Using Participatory Action Research: A Case Study from Guatemala. Journal of Human Resource and Sustainability Studies, 3, 28-33. http://dx.doi.org/10.4236/jhrss.2015.31004

[6] Anderson, F. and Al-Thani, N.N.J. (2015) Sustainability Atlas of Texas Ecoregions. Journal of Human Resource and Sustainability Studies, 3, 203-210. http://dx.doi.org/10.4236/jhrss.2015.34026

[7] Williams, K., et al. (2000) Sea-Level Rise and Coastal Forests on the Gulf of Mexico.

[8] Johnson, T. (2007) Battling Seawater Intrusion in the Central \& West Coast Basins. WRD Technical Bulletin.

[9] Chowdhury, A.H. and Turco, M.J. (2006) Geology of the Gulf Coast Aquifer, Texas. In: Mace, R.E., et al., Eds., Aquifers of the Gulf Coast of Texas: Texas Water Development Board Report.

[10] TWDB (2016) Gulf Coast Aquifer. http://www.twdb.texas.gov/groundwater/aquifer/majors/gulf-coast.asp 
[11] Anderson, F. (2016) Application of Multivariate Geostatistics in Environmental Epidemiology: Case Study from Houston, Texas. Journal of Geoscience and Environmental Protection, accepted.

[12] Anderson, F. (2016) Assessing the Association between Heart Attack, High Blood Pressure, and Heart Disease Mortality Rates and Particulate Matter and Socioeconomic Status using Multivariate Geostatistical Model. Occupational Diseases and Environmental Medicine, 4, 8-15. http://dx.doi.org/10.4236/odem.2016.41002

[13] Anderson, F. (2016) Application of Multivariate Geostatistics in Environmental Epidemiology: Case Study from Houston, Texas. Journal of Geoscience and Environmental Protection, accepted.

[14] Anderson, F. and Al-Thani, N. (2016) Case Study: Reviewing Methods of Assessing Community Adaptive Capacity for Jefferson County, Texas. American Journal of Climate Change, 5, 8-14. http://dx.doi.org/10.4236/ajcc.2016.51003

[15] Anderson, F. and Burau, K. (2015) Back to Basics: Is Civic Agriculture the Solution to Food Deserts in Texas? Open Journal of Social Sciences, 3, 82-89. http://dx.doi.org/10.4236/jss.2015.35012

[16] Anderson, F., Carson, A., Whitehead, L. and Burau, K. (2015) Age, Race and Gender Spatiotemporal Disparities of COPD Emergency Room Visits in Houston, Texas. Occupational Diseases and Environmental Medicine, 3, 1-9. http://dx.doi.org/10.4236/odem.2015.31001

[17] Anderson, F., Carson, A., Whitehead, L. and Burau, K. (2014) Spatiotemporal Analysis of the Effect of Ozone and Fine Particulate on CVD Emergency Room Visits in Harris County, Texas. Open Journal of Air Pollution, 3, 87-99. http://dx.doi.org/10.4236/ojap.2014.34009

[18] Anderson, F. and Najla, N.J. (2016) Exploratory Analyses for Water Quality of the Gulf of Mexico Basin, Texas, 2005-2014. Journal of Geoscience and Environment Protection, 4, 58-63. http://dx.doi.org/10.4236/gep.2016.41007

[19] Barlow, P. and Reichard, E. (2010) Saltwater Intrusion in Coastal Regions of North America. Hydrogeology Journal, 18, 247-260.

[20] USGS (2000) Is Seawater Intrusion Affecting Ground Water on Lopez Island, Washington?

[21] Oden, J.H., Brown, D.W. and Oden, T.D. (2011) Groundwater Quality of the Gulf Coast Aquifer System. U.S. Geological Survey Data Series, USGS, Houston, TX.

[22] EPA (2016) Secondary Drinking Water Standards: Guidance for Nuisance Chemicals. http://www.epa.gov/dwstandardsregulations/secondary-drinking-water-standards-guidance-nuisance-chemicals

[23] Whiteman, K.J., et al. (1983) Occurrence, Quality, and Use of Ground Water in Orcas, San Juan, Lopez, and Shaw Islands, San Juan County, Washington, in Water-Resources Investigations Report.

[24] NOAA (2016) Sea Level Trends. http://tidesandcurrents.noaa.gov/sltrends/sltrends.html

[25] TWDB (2016) Groundwater Database Reports. http://www.twdb.texas.gov/groundwater/data/gwdbrpt.asp

[26] USGS (2014) Estimated Use of Water in the United States County-Level Data for 2010.

[27] Anselin, L., Syabri, I. and Kho, Y. (2006) GeoDa: An Introduction to Spatial Data Analysis. Geographical Analysis, 38, 5-22. http://dx.doi.org/10.1111/j.0016-7363.2005.00671.x

[28] ESRI (2015) ArcMap 10.3.1. Redlands, CA.

[29] Fotheringham, A.S., Charlton, M.E. and Brunsdon, C. (1998) Geographically Weighted Regression: A Natural Evolution of the Expansion Method for Spatial Data Analysis. Environment and Planning A, 30, 1905-1927. http://dx.doi.org/10.1068/a301905

[30] Schabenberger, O. and Gotway, C.A. (2004) Statistical Methods for Spatial Data Analysis. Chapman and Hall/CRC, Boca Raton, 512 p.

[31] Anderson, F. (2014) Multivariate Geostatistical Model for Groundwater Constituents in Texas. International Journal of Geosciences, 5, 1609-1617. http://dx.doi.org/10.4236/ijg.2014.513132

[32] EPA (2015) Changing Rain and Snow Patterns. http://www3.epa.gov/climatechange/kids/impacts/signs/precip-patterns.html

[33] TWDB (2011) Estimation of Groundwater Recharge to the Gulf Coast Aquifer in Texas, USA.

[34] Jevrejeva, S., Moore, J.C. and Grinsted, A. (2010) How Will Sea Level Respond to Changes in Natural and Anthropogenic Forcings by 2100? Geophysical Research Letters, 37. http://dx.doi.org/10.1029/2010gl042947

[35] Taylor, R.G., et al. (2013) Ground Water and Climate Change. Nature Climate Change, 3, 322-329. http://dx.doi.org/10.1038/nclimate1744

[36] Winkler, A. (2013) Treidel H, Martin-Bordes JL, Gurdak JJ (eds) Climate Change Effects on Groundwater Resources: A Global Synthesis of Findings and Recommendations. Environmental Earth Sciences, 70, 1937-1939. http://dx.doi.org/10.1007/s12665-013-2636-0

[37] Alley, W.M., Healy, R.W., LaBaugh, J.W. and Reilly, T.E. (2002) Flow and Storage in Groundwater Systems. Science, 296, 1985-1990. http://dx.doi.org/10.1126/science.1067123 
[38] FAO (2004) Water Desalination for Agricultural Applications.

[39] TWDB (2016) Historical Groundwater Pumpage.

http://www.twdb.texas.gov/waterplanning/waterusesurvey/historical-pumpage.asp 